\title{
特集／眼科とレーザー
}

\section{Scanning Laser Ophthalmoscope を用いた 眼底疾患の治療 \\ Role of a Scanning Laser Ophthalmoscope in Understaning of Fundus Diseases and Therapies}

\author{
白木 邦彦, 高萃 行男, 河野 剛也, \\ 森脇 光康, 三木 徳彦 \\ 大阪市立大学医学部眼科学講座 \\ 干545大阪附大阪市阿培野区九旭町 1-5-7 \\ TEL 06-645-2176 FAX 06-634-3873
}

\author{
Kunihiko SHIRAKI, Yukio TAKAMINE, Takeya KHONO, \\ Mitsuyasu MORIWAKI and Tokuhiko MIKI. \\ Department of Ophthalmology. Osaka City University Medical School \\ Asahimachi 1-5-7, Abeno-ku, Osaka-shi, Osaka, 545 JAPAN
}

\begin{abstract}
要 旨
走查型レーザー娭眼鏡の特徴を生かして，(1)眼底の脈絡膜母斑に対して単色光観察，(2)中心 性漿液性絧脈絡膜症の脈絡膜循環遅延に関してインドシアニングリーン営光眼底造影像でのデ ジタル画像解析，(3) microperimetryを使用して眼底ドルーゼンでの絧膜感度測定を行った。 脈絡膜母班は，近赤外光でするダイオードレーザーを光源とした場合暗視野方式の観察により

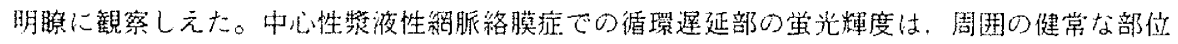
に比して明らかな色素流入の遅れが確認された。眼底のドルーゼン部では網膜感度の低下がみ られた。走查型レーザー梚眼鏡は種々の機能を有し, 眼底病变の形態变化, 眼底腯環の買常, さらには視機能買常の蚞出なざ眼底疾患の病態把握上それに続く治療に今後ますます寄与する ものと思执た。

キーワード：走查型レーザー検眼鏡. microperimetry, 脈絡膜母玟, 中心性漿液性絧脈絡 膜症. ドルーゼン
\end{abstract}

\begin{abstract}
Advantages of a scanning laser ophthalmoscope enabled us to perform three studies : (1) monochromatic light observation on choroidal nevi, (2) digital limage analysis on indocyanine green angiograms of central serous chorioretinopathy, (3) microperimeiry for retinal sensitivity over drusen. Choroidal nevi were clearly observed using a diode laser as a light source and dark field observation. Delay in choroidal perfusion was digitally confirmed in central serous chorioretinopathy. Retinal sensitivity was significantly decreased over drusen. Multifunctional characteristics of a scanning
\end{abstract}


laser ophthalmosope was considered to contribute to analysis of changes in ophthalmoscopic appearance, circulation disturbance and visual functions.

Key words : scanning laser ophthalmoscope, microperimetry, choroidal nevus, central serous chorioretinopathy, drusen.

\section{緒 言}

走查型レーザー梌眼鏡 (scanning laser ophthalmoscope）では，開発初期にFlying spot TV ophthalmo scope"上称されたように，レーザーが眼底上を走查す る。そして眼底上を順次走查していくと同時に眼底から 返ってくる光を検知器で捉え, コンピューター上に眼底 像を再構筑し、テレビモニターに眼底像を映し出す(図 1 )。 従来から使用されている眼底観察のための梌眼鏡や眼底 カメラ撮影装置と比較すると,このシステムには 4 つの 利点がみられる。すなわち，(1)光源にレーーザーを在使用す るこ之，(2)レーザーが眼底を走查するため，ある瞬時に は眼底の一点のみしか照明していないこと，(3)検知器の 前にある開口絞りを变えることで眼底より返ってくる光 のうち必要な光だけを選択できること，(4)眼底を走查す る際レーザーの強さを变化させることで，故る形状パ ターンを眼底に投影できること（図 2)，である”。こ 北らの利点の組み台わせにより，1台の器械に種々の機 能を持たせることができる。以下，走查型レーザー娭眼 鏡の種々の機能について我々の経験を述べる。

\section{I 単色光による眼底観察}

(1)の各種波長のレーザーを光源とすることで，各種単 色光による眼底観察が容易となる。従来より，白色光を 各種バンドパスフィルターに通すことに上り単色光を得，
それを光源として娭眼鏡による眼底観察や、眼底カメラ による眼底撮影を行ってきた。。その結果，眼底網膜血管 および硝子体絪膜境界面での模様病変部の観察には緑色 光などの短波長の光が有用であり、メラニン色素を有す る种膜色素上皮に稪われているため通常の白色光では透 見困難な脈絡膜の観察には赤色光の長波長の光が有用で あるとされている”。しかしながら、このような装置で は白色光観察で得ら机る情報の一部を取捨選択している にすぎず，単色光観察でもって初めて捉えうる新しい所 見を提供することはなかった。しかし走相型レーザー検 眼鏡では，(1)の光源に硝子体紹膜境界面での病変の観察 に適している短波長の光，すなわちアルゴンレーザー(4 $88 / 514 \mathrm{~nm}$ ) を使用すること，(2)のレーザーによる眼 底走查方式による照明により，コントラストの良好な眼 底像が得ら扟ること，(3)の検知器の前にある開口絞りを 小さくすることで共焦点方式の観察，すなわち眼底上り 返ってくる光のうち焦点面からの直接的反射光だけを捉 えるこどでより鮮明な眼底像が得られるようになる (图 3)。こ机らの利点により，硝子体網膜境界面に存在 する網膜前膜を通常の白色光による観察よりも明膫に把 握できるようになる2”。さらに（100光源として近赤外 光のダイオードレーザー $(780 \mathrm{~nm})$ を使用することで, メラニン色素を有する網膜色素上皮を観察光が透過しや

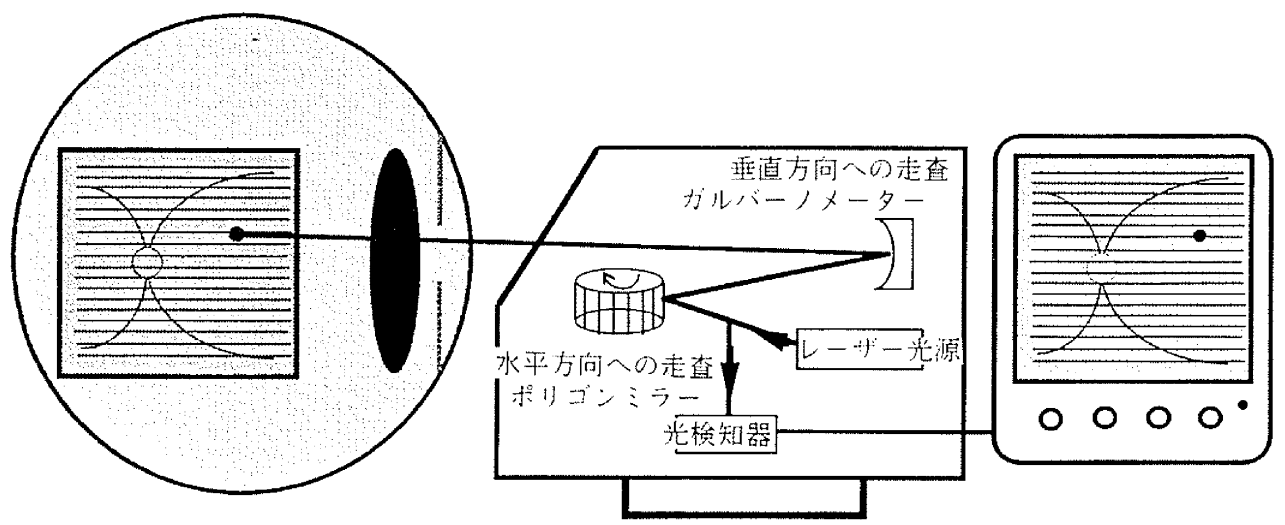

図 1 走査型レーザー検眼鏡 


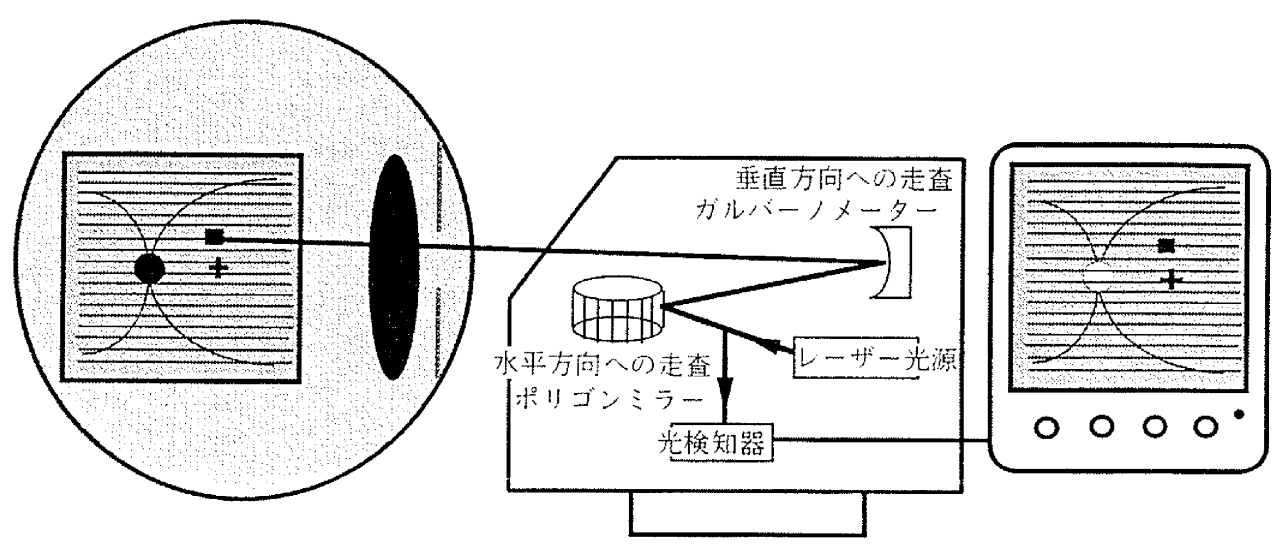

図 2 走査型レーザー検眼鏡によるmicroperimetry

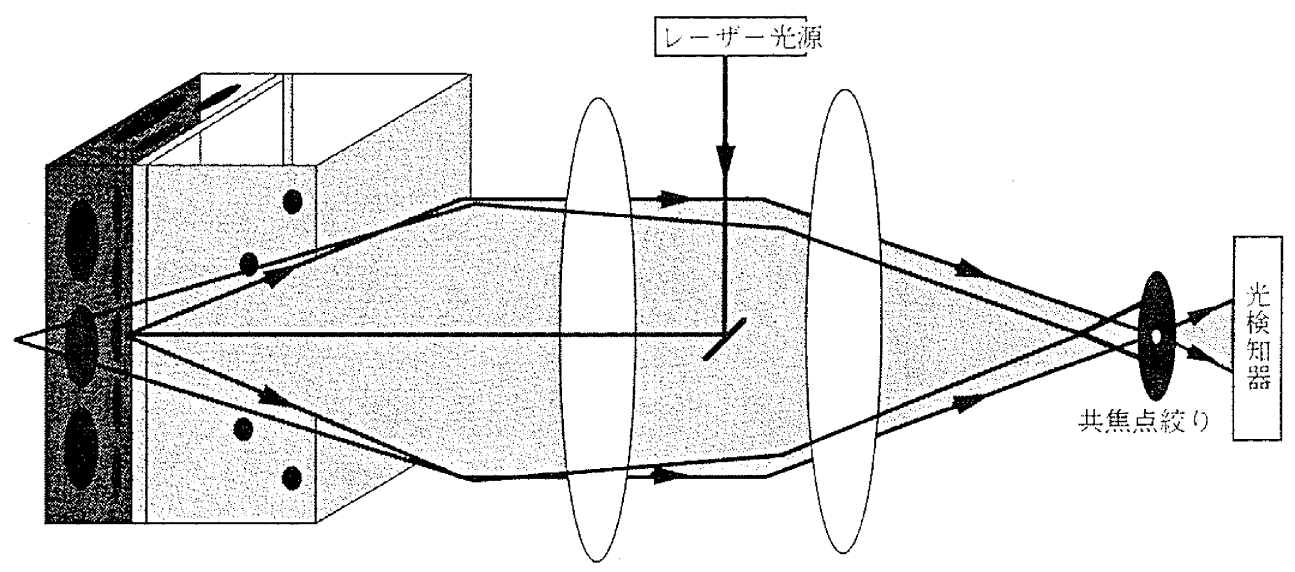

図 3 走查型レーザー検眼鏡による共焦点方式での観察 (文献 4) より改变) 焦点面加の直接的反射光だけを検知器でよらえる。

すくなり，脈絡膜の観察が可能亡なる。さらに(3)の検知 器の前にある開口较りに暗視野较り(リングアパ チャー）を用いると，眼底より返ってくる光のうち散乱 光や間接的反射光だけを捉えることができるようにな

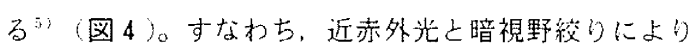
散乱傾向の強い脈絡膜病变や光の吸収傾向の強い脈絡膜 病变が観察可能上なる。本編ではまず第一に，単色光観 察により眼底造影榙查と同程度に脈絡膜母斑の範用を描 出できた我々の経験”を述べる。

\section{II 螢光眼底造影}

(1)の光源にアルゴンレーザーまたは近赤外光のダイ オードレーザーを使用するこし，そして(3)の蚞知器の前 にある開四皎りの代わりに、フルオレセイン螢光用まな はインドシアニングリーン用のバリアフィルターを設置
するこよにより，フルホレセインまたは，インドシアニ

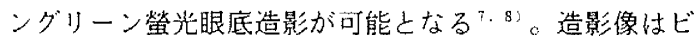
デオ画像として出力されるため，1秒間あたり30フレー ムの画像が得ら机動的な眼底循環の観察が可能である。 その際，(2)のレーザーによる眼底走查方式による照明に より，コントラストの是好な眼底候が得られるため, 彷 来の眼底カメラ撮影装置を使用する埸台よりも少量の造 影倣で撮影が可能である。さらに，ビデオ信号をコン ピューターでデジタル化することにより，画像上での螢 光輝度の時間的な变化から眼底の偱環動態を解析するこ とが可能となる。その際, (2)のレーザーによる眼底走查 方式による照明であるため, 従来の眼底力メラ撮影装置 に比べて画面上での照射光強度のムラが少ないと思われ る。すなわち, 螢光輝度の强度上その部位での螢光色素 


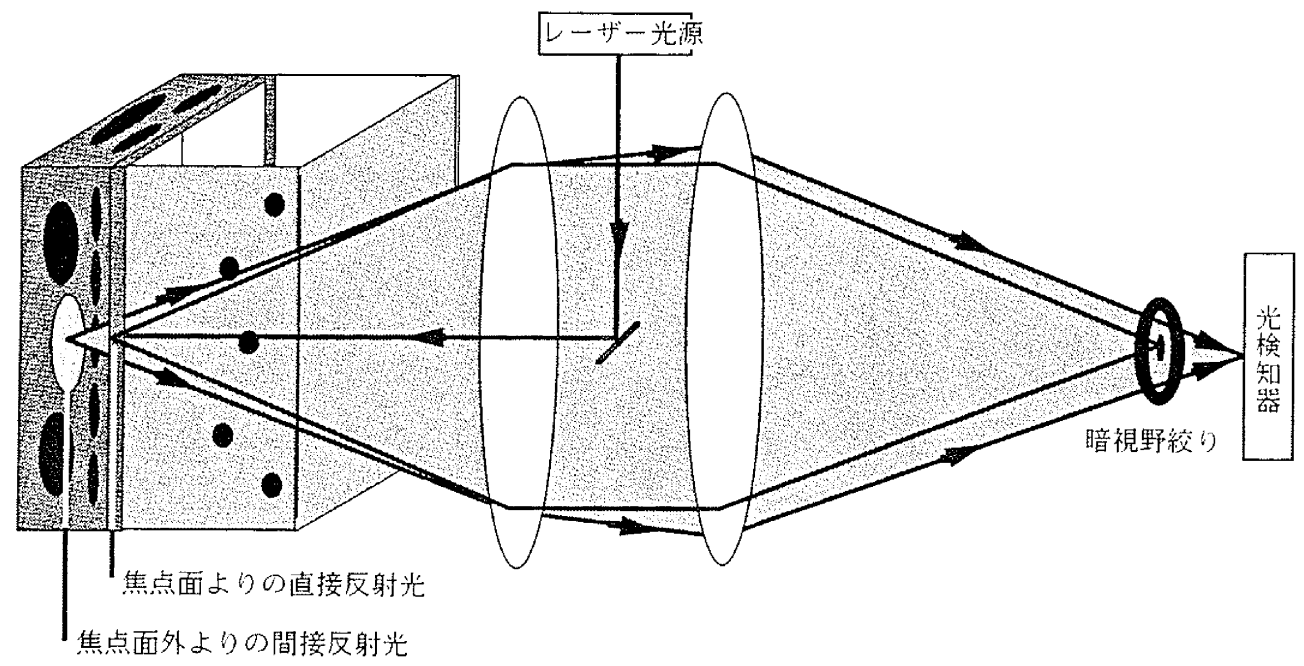

図 4 走查型レーザー梌眼鏡による暗視野方式での観察(文献 4 )より改変)

焦点面からの直接的反射光を開口皎りの真ん中で阻止し, その周囲のリング状の開口部を通ってくる散 乱光や間接的反射光を検知器で捉える。この場合，焦点面以外からの像が観察できる。

鼠との相関が画像上で一定していることから，螢光輝度 の变化が循環動態の变化をよりよく反映していると考え られる。以下本編の第二として，インドシアニングリン螢光眼底造影での眼底循環变化に関して行ったデジタ ル画像解析の経験を紹介する。

\section{III 視機能検查}

(4)の眼底走查の際, 走查型レーザー検眼鏡内の modulatorによりレーザー強度を変化させることで様々な形 状パターンを眼底に投影できる。この利点により，現在 microperimetry(微小視野計測)およびvisumetry (視 力测定）が可能である。 microperimetryについては, 眼底在観察しながら任意の大きさの指標を任意の輝度で 眼局局所に提示することでその部位の網膜感度を測定す ることができる。加龄性黄斑变性や黄斑円孔などの眼底 病変部位での網膜感度の变化がすでに報告されてい

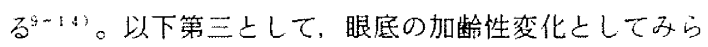
れるドルーゼン部について行った網膜感度娭查を紹介する。

\section{対象および方法}

\section{I 単色光による眼底観察}

\section{脈絡膜母斑の近赤外光およひ暗視野方式による観察}

検眼鏡的に脈絡膜母斑のみら饥た 5 眼 5 例（男性 3 例，

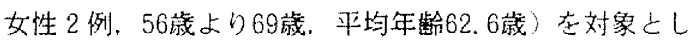
た。走查型レーザー検眼鏡(ローデンストック社製 SLO-101) を用いて、ヘリウムネオンレーザー(633nm) 扰よびダイオードレーザー $(780 \mathrm{~nm})$ を光源とし，共 焦点観察方式のコンフォーカル（C）アパチャーと暗視 野観察方式のリング（R）アパチャーを用いて散睡下に
単色光観察を施行した。記録にはUマチックビデオテー プ(ソニー)を使用した。なお，被検者の同意のもとに フルオレセイン螢光眼底造影およびインドシアニング リーン螢光眼底造影 (インドシアニングリーン25㫙を 2 $\mathrm{ml}$ の添付蒸留水で溶解し，手背静脈より急速注射）を 同装置を用いて施行し，単色光観察での脈絡膜母斑の描 出範囲と比較した。

\section{II 螢光眼底造影}

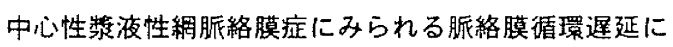
ついてのデジタル画像解析

検眼鏡的およびフルオレセイン螢光眼底造影により中 心性獎液性網脈絡膜症亡診断され，かつ走查型レーザー 娭眼鏡（ローデンストック社製SLO-101）によりイン ドシアニングリーン螢光眼底造影を施行した症例で，イ ンドシアニングリーン螢光眼底造影上脈絡膜循環遅延が 存在すると思われた 8 眼 8 例（男性 5 例，女性 3 例，29 藏から54歳. 平均43.1藏) を対象とした。Uマチックビ デオテープに録画したインドシアニングリーン螢光造影 像をデジタル画像システムであるIMAGEnetシステム (トプコン社)に取り込み, 得られた画像について螢光 色素が眼底に出現し始めた画像より2 秒間隔の画像につ いて螢光輝度の测定を行った。なお，螢光輝度は256階 調のgray level上して表示された。測定部位については， テーブを再生して循環遅延の疑われる部位掞よび遈延の ない上思われる部位，备3，4 力所を選択し，各画像に おいて眽絡膜血管および繰膜血管の走行を基準に各々の 部位を同定しだ。なお，同定した测定部位に脈絡膜動静 脈がみられる場合にはそのすぐ近傍でしかも動静脈にか 


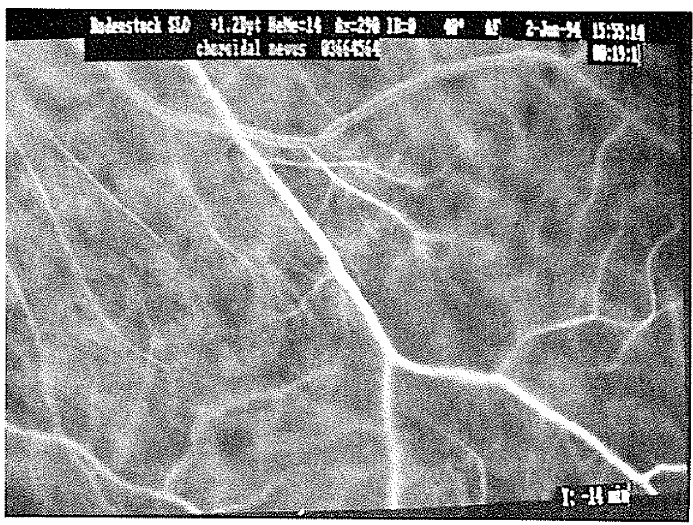

涩 5 a

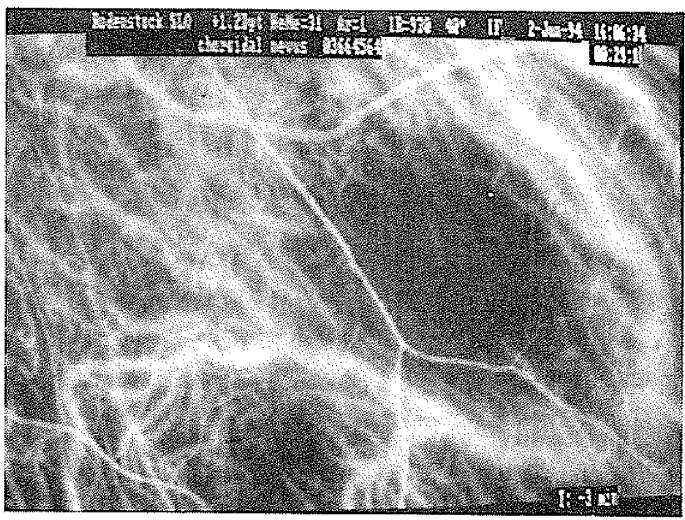

图 5 b

图 5 脈絡膜母斑（55歳，女性）

図 5 a フルオレセイン螢光眼底造影像，図 5 bインド シアニングリーン螢光眼底造影像

からない部位で测定した。輝度の測定にはIMAGEnet システムに搭載されている“Density probe”存使用し， 原画像での各選択部位に执いて $6 \times 6$ ピクセルの範聞で 輝度平均値そ 3 回测定しその平均値を同部位の輝度とし， 時間経過と各部位での輝度变化を検討した。

\section{III 視機能検査}

眼底ドルーゼン上での網膜感度

眼底に十分な大きさの融合性ドルーゼンのみら犯た19 眼16例（42歳から86歳，平均69歳）を対象に，走查型 レーザー䄓眼鏡（ローデンストック社製SLO-101）に 落载されているmicroperimetryを用いて検討した。な 㧍, 絧膜下出血, 螕膜浮腫, 獎液性絧膜剝離なよ゙の渗出 性病变，ならびに網膜色素上皮菱箱なよ゙のみられる部位 でのドルーゼンは対象から除外した。測定部位の光刺激 には， microperimetryを用いて眼底に提示可能な指標 のうちでゴールドマン 2 (視角11分)の大きさを用いた。 したがって，湘定対象としたドルーゼンは，指標ゴール

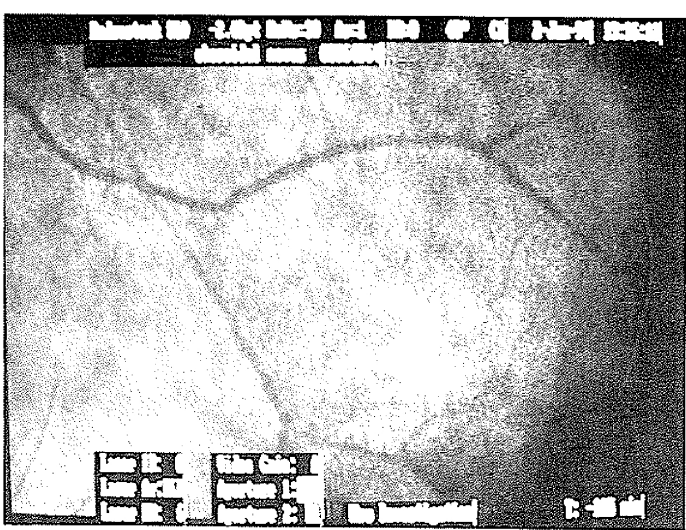

図6 a

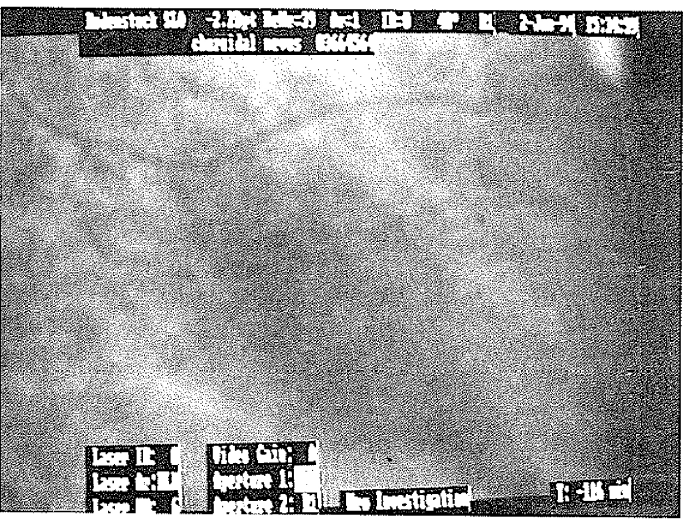

図 6 b

図 6 脈絡膜母斑のヘリウムネオンレーザーによる 走査型レーザー検眼鏡単色光観察

図 $6 \mathrm{a}$ 共焦点方式での観察, 図6 b 暗視野方 式での観察

共焦点方式では脈絡膜母斑は明瞭ではないが, 暗視野方式では暗く描出されている。

ドマン 2 (視角11分) の大きさよりも大きいドルーゼン を対象とした。なお，指摽の提示時間は 0.1 秒，背罢輝 度は $10 \mathrm{~cd} / \mathrm{mm}^{2}$ とし，指標の背景輝度より暗い部屋で, 輝度の低い指標から輝度の高い指標を順次提示すると之 もに逆に輝度の高い指標加輝度の低い指標をも順次提 示して，その部位が認識する最低指標輝度を求めた。ま た、ドルーゼン周畘の健常な部位での絧膜感度を測定し， ドルーゼン部での網膜感度が $5 \mathrm{~dB}$ 以上低下している場 台を網膜感度低下とした。また、ドルーゼン部の網膜感 度低下について $\mathrm{t}$ 蚞定在用いて統計学的に検討した。

\section{結 果}

\section{I 単色光による眼底観察}

脈絡膜母斑の近赤外光および暗視野方式による観察 5 眼 5 例の全例においてフルオレセイン螢光眼底造影 


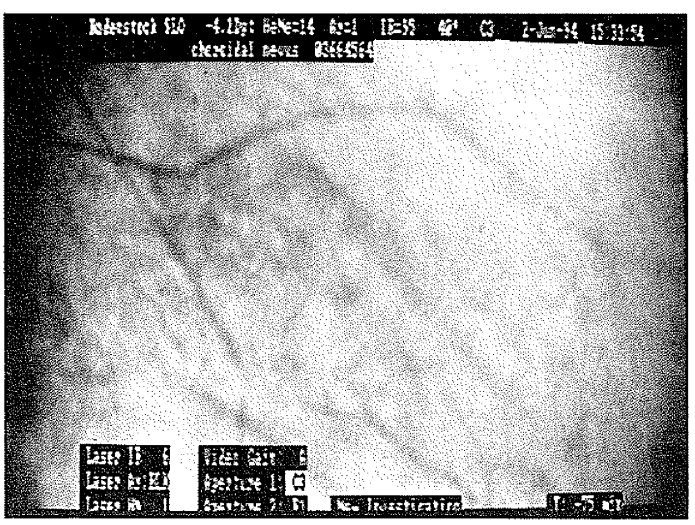

成 7 a

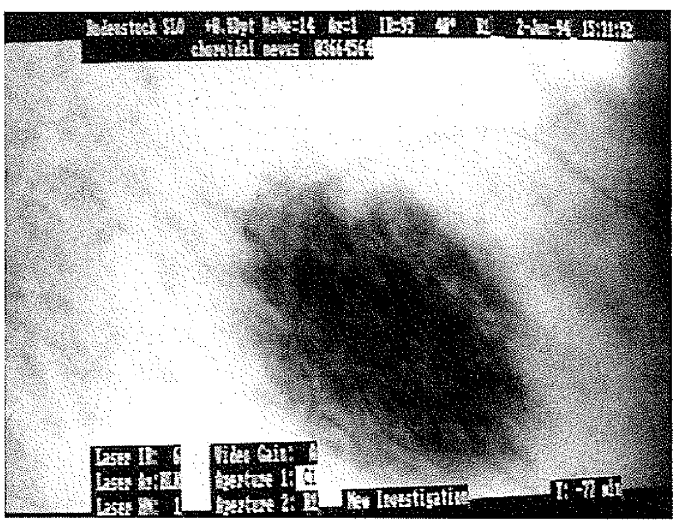

园 $7 \mathrm{~b}$

図 7 脈絡膜母斑のダイオードレーザーによる走査型 レーザー検眼鏡単色光钼察

図 $6 \mathrm{a}$ 共焦点方式での観察，図 $6 \mathrm{~b}$ 暗視野方式 での観察

共焦点方式での観察では明瞭ではないが，暗視 野方式では母斑がインドニアニングリーン螢光 造影でみられるように明瞭に描出されている。

では母斑の境界は明瞭ではなかった（図 5 a)。また。 走查型レーザー検眼鏡を使用した場合でも共焦点観察方 式のコンフォ一カル（C）アパチャ一使用した場合，赤 色光のヘリウムネオンレーザーでも近赤外光のダイオー ドレーザーでも母斑は明睹には描出されなかった（図 6 a，7 a )。しかし，暗視野観察方式のリング（R）ア パチャーを使用すると母斑は両レーザーでともに描出さ れ（図 $6 b ， 7 b)$ ，特に近赤外光であるダイオード レーザーを使用するよインドシアニングリーン螢光眼底 造影で描出さ扎たと同じ範囲（図 5 b）で脈絡膜母斑が 明瞙に描出された。

II 螢光眼底造影

中心性墏液性絧脈絡膜症にみられる脈絡膜循罢遅延に ついてのデジタル画像解析

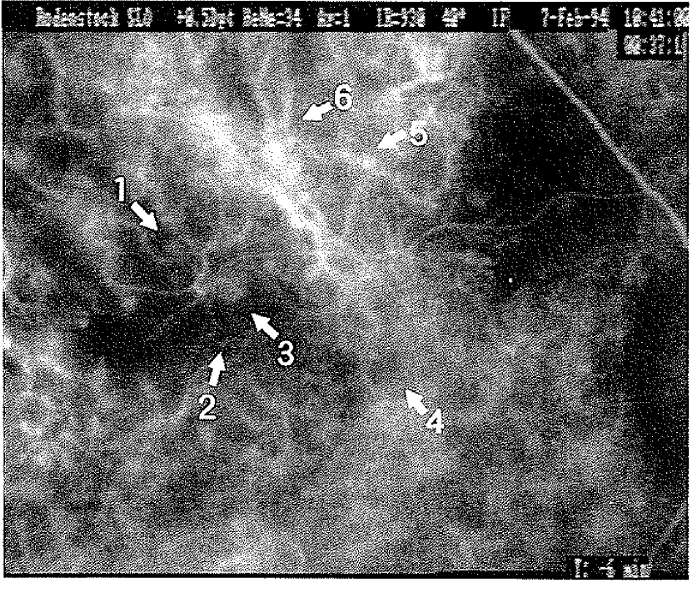

国 8 a

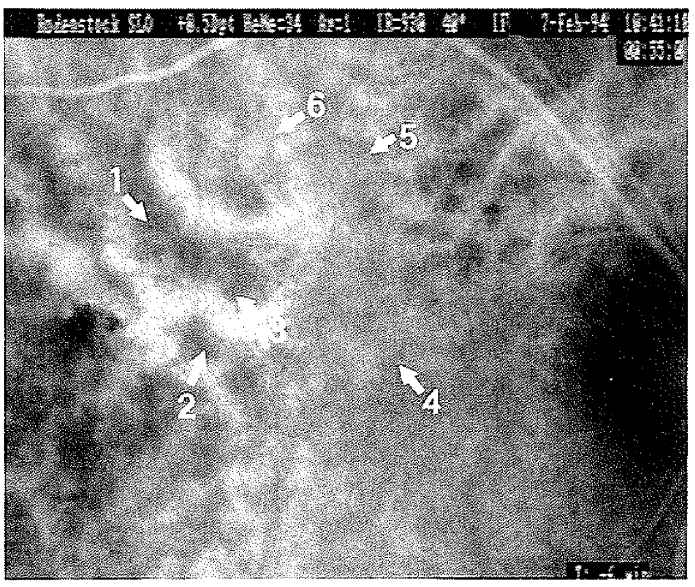

図 $8 \mathrm{~b}$

図 8 中心性漿液性絧脈絡膜症のインドシアニング リーン螢光眼底造影（43歳，男性）

図 8 a 造影開始後37.1 秒, 図 8 b 造影開始後 55. 0秒

造影開始後37.1秒では矢印1 から3の部では， 知印 4 から 6 までの部位に比べて螢光色素の流 入がおくれているが，造影開始後55.0秒では循 環の遅延は明らかではない。

インドシアニングリーン螢光眼底造影で脈絡膜偱環の 遅延がある上思わ机た部位（図 8) では，色素流入の正 常之思われる周囲の部位に比べて，8眼8例の全症例に おいて螢光輝度の增加率が低かった。そのうち，5眼 5 例では造影開始後 8 秒から20秒後になって初めて, 周囲 の循環達延のない上思われる部位上同程度の螢光輝度を 示すようになった（図９）。ただし，残りの3眼 3 例 では周囲の輝度之比較して低䚜度を示したままであっ た。 


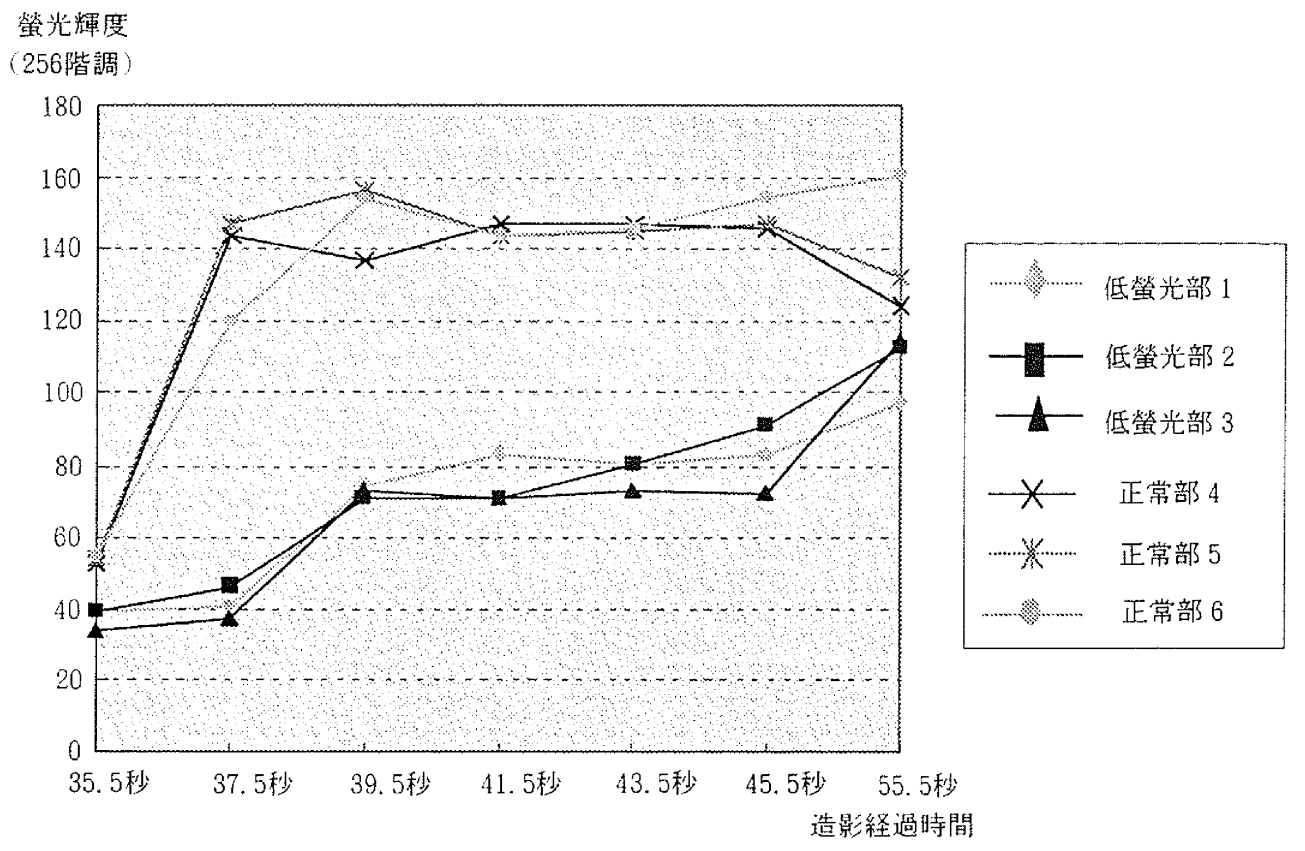

図 9 中心性璘夜性網脈絡膜症での螢光辉度に関するデジタル画像解析

縦軸：256階調で示した螢光輝度, 横軸：造影経過時間

造影開始後 55.0 秒になって, 知 1 から 3 の部位と知 4 から 6 までの部位での螢光輝度が同程度に なっている。すなわち知 1 から 3 の部位では循環遲延が存在している。

\section{III 視機能検查}

眼底ドルーぜン上での絧膜感度

19 眼16例中，網膜感度最小閾值を測定した融合性ド ルーゼンは29個であった。これら，29個のうち15個にお いて周囲健常網膜部位と比較して $5 \mathrm{~dB}$ 以上の網膜の感 度低下がみられた（図10）。この融合性ドルーゼンでの 網膜感度低下は周团の網膜感度上比较する之統計学的に 有意であった。( $\mathrm{p}<0.02)$

\section{考 察}

\section{I 単色光による眼底観察}

眼底観察の際，網膜は直視下に観察可能であるが，脈 絡膜は網膜色素上皮中のメラニン色素によって隐蔽され 大きな脈絡膜血管しか透見できない。また，眼底疾患の 病態解明には従来よりフルオレセイン螢光眼底造影が有 用であるが，フルオレセインの螢光は網膜色素上皮中の メラニン色素によって吸収されるため、脈絡膜病変の詳 細を捉えることはできない。近年臨床使用されつつある インドシアニングリーン螢光眼底造影は，その色素の螢 光が近赤外光領域にあり網膜色素上皮中メラニン色素を 透過するため，眽絡膜病变の描出が可能である。今回の 脈絡膜母斑でも，フルオレセイン螢光眼底造影では母斑
の全体像を捉えることは不可能であったが，インドシア ニングリーン螢光眼底造影によって初めて病变部の籍囲 を捉えることができた。しかしながら，螢光眼底造影検 查では薬剮を体内に投与する以上アナフィラキシー ショックの可能性を完全には否定できない。したがって， 非侵熋的な検查が望まれるところである。そこで，従来 より赤色光での脈絡膜病変の観察が試みられていた15)。 しかし，今回の観察にみられたように，赤色光であるへ リウムネオンレーザーでは絴膜色素上皮中のメラニン色 素での透過が不十分で，脈絡膜母斑は明瞙に描出されな かった。しかしながら，網膜色素上皮中のメラニン色素 での透過が良好な近赤外光であるダイオードレーザーを 使用すると，眽絡膜母斑の範囲がより明瞭に描出された。 このように観察対象となる病変の存在部位によって使用 する観察光の波長を選択することは重要で，網膜硝子体 境界面の病変である網膜前膜の観察に際しても，ヘリウ ムネオンレーザー $(633 \mathrm{~nm})$ よりも短波長であるアル ゴンレーザー $(488 / 514 \mathrm{~nm})$ を使用した方がょり広範 囲に膜様病変部が観察できる”。

また，走查型レーザー検眼鏡では，光検知器の前に絞 りを置くことで観察対象部位からの直接反射のみを捉え る共焦点方式の観察や, 散乱光および間接的反射光のみ 


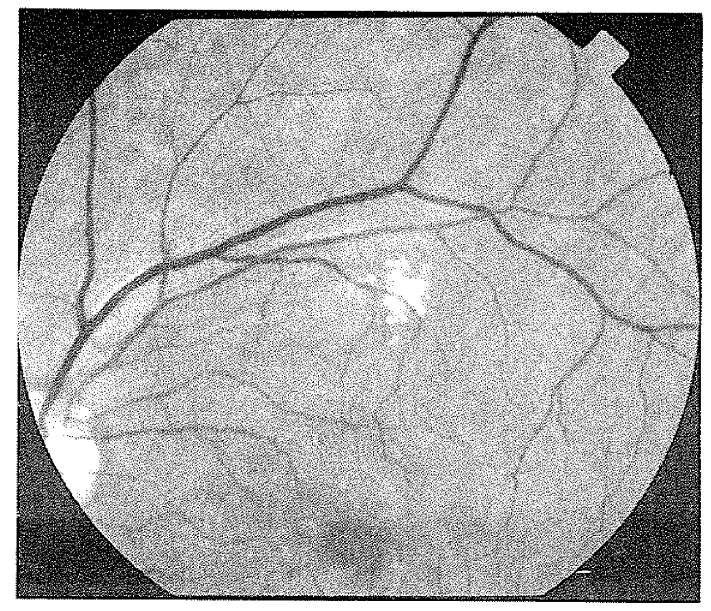

河 $10 \mathrm{a}$

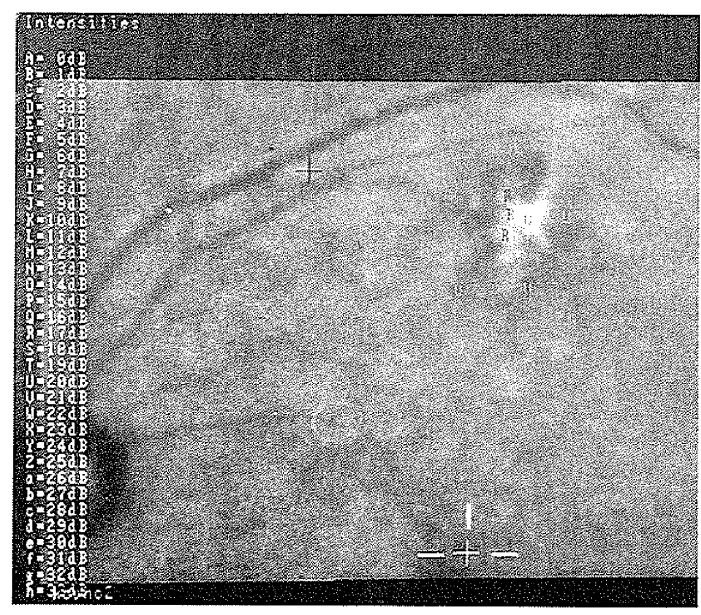

図10b

図10 眼底ドルーゼン上での網膜感度（62歳，女性） 图10 a 眼底写真, 図10b SLOによるmicroperimetry 明るく描出されているドルーゼン部では16から17 dBの 指標がわかるが、その周囲の健常な網膜では上り暗い20 $\mathrm{dB}$ の指標に対しても認知できる。

を捉える暗視野方式の観察ができる。直接的反射光のみ を捉える共焦点方式の観察では，網膜硝子体境界面の病 变である䌌膜前膜のように直視下に観察できる病变部に ついては良好なコントラストで観察が可能である2!。し かしながら、既報告”のように視神経乳頭組織に埋没し た乳頭部ドルーゼのように，組織に埋没した病変部につ いては病变部からの直接的反射光を捉えにくいため、む しろ散乱光および間接的反射光のみを捉える暗視野方式 の観察の方が病变部位が良好に描出される。今回の脈絡 膜母斑では，暗視野方式の観察を行うことで脈絡膜由来 の散乱光や間接的反射光で脈絡膜全体が明るく高輝度に 描出されたが，それらの光が脈絡膜母斑によって吸収さ
れることで，母斑部がコントラスト良く暗く描出された 亡舁才扎る。

このように，観察対象である病变部の病理学的性状之 その病变部が存在する組織の光学的性状走上く理解する ことによって、螢光眼底造影蚞查に依存することなく病 变部が良好に描出されることが明的かよなった。

\section{II 螢光眼底造影}

螢炕眼底造影装犆には、眼底を全体にわたって一度に 照明する眼底力メラ装置が彷来より使用されてきた。 の眼底力メラ装置で得られる造影像では、レンズ光学系 に上る像の昰みとともに，眼底の照明が一様でないとい う欠点がある。光学系による像の歪みは走査型レーザー 娭眼鏡でも少なからず存在する。しかし眼底の照明に関 しては、レーザ一が眼底を走查し，ある一㮩ではレー ザーはある一点のみしか照明していないことから，眼底 カメラ装䇴上りも，眼底の照明強度のムラは少ない上思

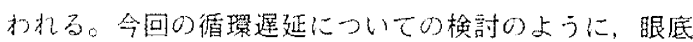

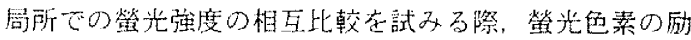
起光が眼底を一様に照明していることが必要である。走

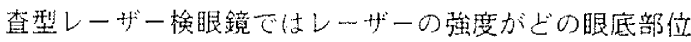
でも一梾であると考兑られるため，得られる螢光強度は その部位に存在する螢光色素量ずなち循環血液量を眼 底力メ亏装置上りも良好に反映しているものと思われる。

今回検討対象とした中心性獎液性網脈絡膜症では，脈 絡膜の循環遅延の有無について一定の見解が得られてい ない。走查型レーザー検眼鏡を用いて検討した報告では 循環遅延が存在するといい16.17, 眼底力メラ装置を用 いた報告では明らかな循環達延はみら扎ず，健常者にみ られる範删内の色素流入の遅机であったと報告してい

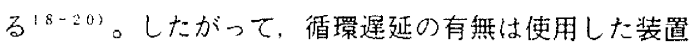
の差によるもの之思われるが，その原因上してやはり眼 底の照明方法の差が影響していると思われる。すなわち， 眼底力メラ装置では一度に眼底全体を照明し，かつ眼底 より螢光を捉える際眼底から返ってくるすべての光を捉 える。したがって，造影色素から眼底カメラ中のCCD 装㯰に直接到達する直接光としての螢光ばかりでなく， 色素から発した螢光が散乱や間接反射をし，その後眼底 カメラのCCD装琶に到達する間接光としての螢光も捉 えていると思われる。よって，本来螢光を示さないはず の循眇遅延部でも間接光のため明るく描出され，循環遅 延部の存在が見落とさ㧈る可能性があるものと思われる。

今回の检討では，前述のように眼底より返ってくる螢 光のうち間接光の影響が眼底力メラ装㯰より少ない走査 型レーザー検眼鏡を用いて循環遅延の有無を検討した。 さらに，螢光輝度の時間的变化を客観的に調べるため， 
螢光造影のビデオ画像をデジタル化し，螢光輝度を256 階調にわけて，2秒間隔で造影経過を検討した。その結 果, 造影開始後 8 秒から 20 秒経過して周囲の部位の螢光之 同程度の輝度を示すようになった部位が 8 眼 8 例中 5 眼 5 例において存在したことは，循環荤延部の存在を証明 するものであると思わ机る。ただし周囲の部位より螢光 輝度が低いままであった 3 眼 3 例については，循噮遅延 以外にメラニン色素塊などによる螢光阻止に起因する可 能性もあるためさらに検討する必要があると思われる。

\section{III 視機能検查}

従来，眼底病变の網膜感度の测定には自動静的星的視 野計が用いら机てきた。しかし, 病变部の感度を直視下 に测定できないため，感度低下部位を眼底において正確 に同定することは困難である。特に，今回測定対象とし たドルーゼンのように小さい病変部位での綢膜感度测定 は不可能である。これまでに，眼底局所の網膜感度を直 視下に測定する装置しして，従来の眼底カメラを改造し， 眼底に指標を投影する装置が開発された。そして絶対暗 順伈下において今回と同様に眼底のドルーゼン上での網 膜感度を検討しているが，ドルーゼン上での網膜感度の 低下はなかった之報告している2゙。今回の検討ではド ルーゼン上で網膜感度の低下がみられ測定結果に差がみ られたが，絶対暗順応下で施行した結果と今回の非絶対 暗順応下での結果を同等に比較することはできない。ド ルーゼンは網膜の視細胞の代謝に活発に関与している網 膜色素上皮の加路性変化として絪膜色素上皮下に残渣物 が沈着し形成されると考えられている22!。ドルーゼン は眼底の加齢性变化としてみられ必ずしも視機能障害を 生じるものではないが、これらの残滇物の沈着の程度お よび性状によっては，網膜色素上皮自体の代謝障害さ れ， 2 次的に網膜視細胞の障害，それに伴う網膜感度の 低下が生じる可能性が考虑される。

現在, 走査型レーザー検眼鏡荙使用した視機能娭查上 しては, 眼底の局所に直接視力表を提示し，その局所で の視力を测定するvisumetryが酚床的に使用可能である。 この検査法は視力測定ばかりでなく，加齢性黄斑変性な ごにより両眼の黄斑が高度に障害された場台，残存する 粗膜において有効に機能する眼底部を被検者に自賞させ， その部位を日常生活に有効に利用させるという，視力障 害者のリハビリテーションのための器械としての可能性 も指摘されている23!。さらに，走查型レーザー検眼鏡 では眼底局所に任意の指標を提示できることから，眼底 同所を刺激した時の視覚誘発脳波を捉える電気生理学的 検查の開発の可能性も存在する"i”。

以上, 笚色光に上る眼底親察, 螢光眼底造影, 視機能
娭湘の3 種類の検查に関して走查型レーザー検眼鏡の有 用性述べたが，走查型レーザー検眼鏡は未だ発達途上 にある。共焦点走查型レーザー検眼鏡システムは，より 解像度の良い螢光眼底造影あるいは他稿に述べられてい るトモグラフィーによる眼底組織像の 3 次元画像化, さ らにレーザードップラーによる眼底血流測定など様々な 可能性を有している。また, 視機能検查装置としての走 査型レーザー検眼鏡システムも今後ますます臨休的に応 用可能となることが期待される。

\section{文 献}

1) Webb RH, Hughes GW, Pomerantzeff O. Flying spot TV ophthalmoscope. Appl Opt $19: 299$ 1-2997, 1980.

2 ) 白木邦彦: 新しい眼底検査法一走査型レーザー検眼 鏡一・眼紀, 47：629-636, 1996.

3 ) Delori FC, Gragoudas ES, Francisco R, Pruett $\mathrm{RC}$ : Monochromatic ophthalmoscope and fundus photography. The normal fundus. Arch Ophthalmol, 95:861-868,1977.

4) Woon WH, Fitzke FW, Bird AC, Marshall J : Confocal imaging of the fundus using a scanning laser ophthalmoscope. Br J Ophthalmol, $76: 470-474,1992$.

5)上野珠代, 白木邦彦, 森脇光康, 河野剛也, 三木徳 彦: 視神経乳頭ドルーゼンの走查型レーザー検眼鏡 所見・跕眼, 49:711-714, 1995.

6 ) 高萃行男, 白木邦彦, 河野剛也, 三木徳彦: 走査型 レーザー娭眼鏡による脈絡膜母斑の単色光観察・眼 紀, 48:86-90, 1997.

7) Nasemann JE, Muller M : Scanning Laser Ophthalmoscopy and Tomography, 63-80, Quintessenz, 1990.

8 ) Scheider A, Schrodel C, Plesch A : Scanning Laser Ophthalmoscopy and Tomography, 97102, Quintessenz, 1990.

9 ) Timberlake GT, Van De Velde FJ, Jalkh AE : Clinical use of scanning laser ophthalmoscope retinal function maps in macular disease. Laser and Light in Ophthalmology 2:211-222, 1989.

10) Sjaarda RN, Frank DA, Glaser BM, Thomps on JT, et al. : Assesment of vision in idiopathic macular holes with macular microperimetry using the scanning laser ophthalmoscope. Ophthalmology $100: 1513-1518,1993$. 
11) 石子智士, 秋葉 純, 梯彰弘他: 走查型レー ザー検眼鏡を用いたmicroperimetryによる黄斑円 孔の固視点・臨眼, 49:415-418, 1995.

13）高窑行男. 白木邦彦, 森脇光康, 尾花 明, 他: 加 龄性黄斑变性におりるインドシアニングリーン螢光 眼底造影後期にみられた明るい螢光部の網膜感度・ 䠦眼, $50: 933-936,1996$.

14）辻川元一，斉滕喜博，井上智之，本倉雅信 他：䅂 子状光凝固術のSLO Microperimetryに上る娭討 - 眼紀, $47: 37-41,1996$.

15) Ducrey NM, Delori FC Gragoudas ES: Monochromatic ophthalmoscopy and fundus photo. graphy. II. The pathologic. Arch Ophthalmol, $97: 288-293,1979$.

16) Scheider A, Nasemann JE, Lund OE. Fluorescein and indocyanine green angiographies of central serous choroidopathy by scanning laser ophthalmoscopy. Am J Ophthalmol $1993 ; 115$ : 50-56.

17) Prunte C, Flammer J. Choroidal capillary and venous congestion in central serous chorioretinopathy. Am J Ophthalmol $1996 ; 121$ : 26-34.

18) Guyer DR, Yannuzzi LA, Slakter JS, Sorenson. JA, Ho, A, Orlock, D. Digital indocyanine green videoangiography of central serous chorioretinopathy. Arch Ophthalmol 1994; 112 : 1057-1062.

19) Piccolino FC, Borgia L. Central serous chorio retinopahty and indocyanine green angiography. Retina $1994 ; 14: 231-242$.

20) Piccolino FC, Borgia L, Xinicora E, Zingirian M. Indocyanine green angiographic findings in central serous chorioretinopathy. Eye 1995 ; $9: 324-332$.

21) Sunness JS, Johnson MA, Massof RW, Marcus $\mathrm{S}$ : Retinal sensitivity over drusen and nondrusen areas. A study using fundus perimetry. Arch Ophthalmol 106 : 1081-1084, 1988.

22) Gass JDM : Diseases causing choroidal exudative and hemorrhagic localized (disciform) detachment of the retina and pigment epithelium. Stereoscpic atlas of macular diseases. 43-219. Mosby, 1987.

23) Fletcher DC, Schuchard RS : Preferred retinal loci relationship to macular scotomas in a low-vision population. Ophthalmology 104 : 632-638, 1997.

24) Katsumi O, Timberlake GT, Hirose $T$, Van de Velde FJ, et al. : Recording pattern reversal visual evoked response with the scanning laser ophthalmoscope. Acta Ophthalmol 67 : 243$248,1989$. 